\title{
Amyloidosis in rheumatoid arthritis: role of serum amyloid A gene (SAA1) polymorphism and Chlamydia trachomatis infection in the Belarusian patient population
}

\author{
Amyloidoza $w$ reumatoidalnym zapaleniu stawów: rola polimorfizmu genu \\ surowiczego amyloidu A (SAA1) oraz zakażenia Chlamydia trachomatis \\ w populacji biatoruskich pacjentów
}

\author{
Nikolay F. Soroka, Anastasiya K. Tushina \\ $2^{\text {nd }}$ Department of Internal Diseases, Belarusian State Medical University, Minsk, Belarus \\ Drugi Oddział Chorób Wewnętrznych, Białoruski Uniwersytet Medyczny, Mińsk, Białoruś
}

Key words: secondary amyloidosis, rheumatoid arthritis, risk factors.

Słowa kluczowe: amyloidoza wtórna, reumatoidalne zapalenie stawów, czynniki ryzyka.

\begin{abstract}
Sum mary
Objective: Amyloidosis is an important severe complication of rheumatoid arthritis (RA). The study was designed to evaluate polymorphism of the gene encoding serum amyloid A as well as Chlamydia trachomatis infection as risk factors of development of amyloidosis in RA patients.

Material and methods: One-hundred and four patients with definite RA were investigated. The patients were divided into two groups, the AA-positive group (secondary amyloidosis confirmed by histopathological evaluation of the tissue sample) (45 patients), and the AA-negative group (59 patients).

The polymorphism of SAA1 and occurrence of Chlamydia trachomatis infection were assayed in all the patients.

Results: No significant differences between the two patient groups in the -13T/C allele frequency were revealed. Therefore, the -13T allele is not obligatory for AA amyloidosis development in Belarusian patients with RA. Comparison of groups for genotype and three allele frequencies showed statistically significant differences. The most notable differences were observed in SAA1 $\alpha / \alpha$ genotype $-\chi^{2}=31.1(p<0.001)$. Forty-three of 45 AA-positive RA patients (96\%) had SAA1 $\alpha / \alpha$ genotype while only $32 \%$ AA-negative RA patients presented this genotype. A similar tendency was observed for allele $\alpha$ frequency: $\chi^{2}=47.01(p<0.001)$.

Up to $84 \%$ of 45 AA-positive RA patients had concomitant Chlamydia trachomatis infection during the course of RA. In the AA-negative group association of RA and the infection was revealed in $10(17 \%)$ of 59 patients only $(p<0.004)$.
\end{abstract}

\section{Streszczenie}

Cel pracy: Amyloidoza jest ważnym, ciężkim powikłaniem reumatoidalnego zapalenia stawów (RZS). Badanie zaplanowano w celu oceny polimorfizmu genu kodującego surowiczy amyloid A, a także zakażenia Chlamydia trachomatis jako czynników ryzyka rozwoju amyloidozy u pacjentów z RZS.

Materiał i metody: Zbadano 104 pacjentów z ustalonym rozpoznaniem RZS. Chorych podzielono na dwie grupy: grupę AA-dodatnią (wtórna amyloidoza potwierdzona $w$ badaniu histopatologicznym próbki tkanki) (45 chorych) oraz AA-ujemną (59 osób).

U wszystkich pacjentów zbadano występowanie polimorfizmu SAA1 oraz zakażenia Chlamydia trachomatis.

Wyniki: Nie stwierdzono istotnych zmian pomiędzy częstością występowania allela -13T/C w obu grupach pacjentów. Allel -13T nie jest obligatoryjny dla rozwoju amyloidozy AA u białoruskich chorych na RZS. Porównanie grup pod kątem genotypu i częstości występowania trzech alleli wykazało statystycznie znamienne różnice. Najbardziej zauważalne różnice obserwowano w przypadku genotypu SAA1 $\alpha / \alpha-\chi^{2}=31,1(p<0,001)$. U 43 z 45 AA-dodatnich pacjentów z RZS (96\%) stwierdzono genotyp SAA1 $\alpha / \alpha$, natomiast u AA-ujemnych pacjentów fenotyp ten występował zaledwie u 32\%. Podobną tendencję obserwowano $w$ zakresie częstości allela $\alpha: \chi^{2}=47,01$ $(p<0,001)$.

Aż u 84\% z 45 AA-dodatnich pacjentów z RZS w przebiegu choroby odnotowano jednoczesne zakażenie Chlamydia trachomatis. W grupie AA-ujemnej powiązanie RZS z infekcją stwierdzono zaledwie u $10(17 \%)$ z 59 pacjentów $(p<0,004)$.

\section{Address for correspondence:}

Prof. Nikolay F. Soroka, Belarusian State Medical University, $2^{\text {nd }}$ Department of Internal Diseases, 220116, Dzerghinski Avenue, 83, tel. +375 1727257 93, fax +375 1727876 10, e-mail: Soroka1949@mail.ru

Submitted: 21.10 .2013 
The odds ratio (OR) calculated for the SAA1 $\alpha / \alpha$ genotype was 45.26 , and the $95 \%$ confidence interval $(95 \% \mathrm{Cl})$ was 9.9-206.8. Odds ratio for Chlamydia trachomatis infection was 26.6 (95\% Cl: 9.26-76.37). Conclusion: Risk of secondary amyloidosis in RA patients significantly depends on SAA1 genotype and the presence of Chlamydia trachomatis infection.

\section{Introduction}

Amyloidosis is a severe and frequently fatal complication of rheumatoid arthritis (RA) [1]. It is a systemic disease characterized by the extracellular deposition of amyloid fibrils derived from the acute-phase reactant serum amyloid A protein (SAA). Despite progress in management of RA resulting in improved functional state of the patients and their better quality of life as well as survival rate, occurrence of cardiovascular events and amyloidosis remains an important clinical problem [2, 3]. Amyloidosis can affect a number of body systems and organs but renal involvement associated with chronic renal failure is considered to be one of the most severe and life-threatening complications of RA [4]. Prevalence of amyloidosis in RA patients is different in various populations but is still relatively high $[5,6]$.

Amyloidosis which is found in patients with RA is a secondary form of the disease resulting from chronic inflammation. Successful treatment of inflammation in RA is a base for remission and protects the patients against structural damage of the joints as well as cardiovascular events and amyloidosis [7]. However, it is known, that remission or low disease activity cannot be achieved in all patients. This phenomenon is closely related to amyloidosis. The complication develops in some patients despite intensive medication [8]. Serum amyloid A is a highly conserved, acute-phase protein synthesized predominantly in the liver. It has been reported that some polymorphisms in the gene SAA1 encoding SAA, the protein partially accumulated in tissue deposits of amyloid, contribute to individual susceptibility to amyloidosis in RA patients [9-11]. Additionally, a relationship between plasma SAA level and development of amyloidosis was evidenced in some researches [12].

Inflammation due to infection is a well-known factor for amyloidosis development. Chlamydia infections have been established as the cause of reactive arthritis especially in some spondyloarthritides. In our previous researches, we have reported coexistence of Chlamydia trachomatis infection with seronegative RA [11]. Thus it is suggested that chlamydial infection is an additional factor enhancing prevalence of amyloidosis in RA patients.

The present research was designed to evaluate the possible role of $S A A 1$ gene polymorphism and Chlamydia trachomatis infection in development of amyloidosis in RA patients.
Iloraz szans (OR) wyliczony dla genotypu SAA1 $\alpha / \alpha$ wynosit 45,26, a 95\% przedział ufności (95\% Cl) 9,9-206,8; OR dla zakażenia Chlamydia trachomatis wynosit 26,6; $95 \% \mathrm{Cl}: 9,26-76,37$.

Wniosek: Ryzyko wtórnej amyloidozy u pacjentów z RZS w sposób znamienny zależy od genotypu SAA1 i obecności zakażenia Chlamydia trachomatis.

\section{Material and methods}

We investigated 104 patients treated in the Belarusian Rheumatological Center in Minsk in 2007-2010, who were diagnosed with rheumatoid arthritis (RA) according to the 1987 revised criteria of the American College of Rheumatology [13]. Amyloidosis was diagnosed by renal, rectal or gingival biopsy, and the patients were divided into those with detected amyloidosis (AA-positive group) and those without amyloidosis (AA-negative group). Tissue samples were stained with Congo red and analyzed in polarized light for bright green birefringence. The AA-positive group ( $1^{\text {st }}$ group) consisted of 45 patients ( 37 female, 8 male; mean age 58). The AA-negative group ( $2^{\text {nd }}$ group) consisted of 59 patients (50 female, 9 male; mean age 52). There were no significant differences in RA activity (SDAI), radiographic stage and RF positivity/negativity between the two groups (Table I).

The SDAl index suggested by Smolen means Simplified Disease Activity Index. In this method the CRP serum level is expressed in mg/dl (0-10) instead of LnESR (as used in all DAS modifications). In brief: SDAI $=$ SJC + TJC +

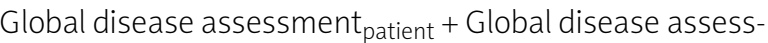
ment $_{\text {physicians }}+$ CRP $(\mathrm{mg} / \mathrm{dl})$.

The duration of RA in both groups was similar: 16.0 $(13 ; 21)$ years in the $1^{\text {st }}$ group and $15.8(12 ; 18)$ years in the $2^{\text {nd }}$ group ( $\left.p P>0.05\right)$.

The majority of patients in the $1^{\text {st }}$ group had used several groups of disease modifying antirheumatic drugs (DMARDs) because of insufficient effectiveness or side effects of the prescribed treatment; furthermore their compliance with the treatment was low. Only 17 (37.8\%) patients in this group had taken DMARDs regularly. Twenty-eight $(62.2 \%)$ patients in the $1^{\text {st }}$ group and $21(35.6 \%)$ in the $2^{\text {nd }}$ group had received glucocorticoids $(p=0.006)$.

\section{Determination of SAA1 genotype}

Native DNA was extracted from blood leucocytes obtained from all investigated patients. For amplification, a segment of the $S A A 1$ gene including the polymorphic sites -13T/C, 2995C/T was genotyped by polymerase chain reaction (PCR) with subsequent restriction enzyme digest analysis. PCR was performed with a MyCycler ${ }^{\mathrm{TM}}$ Thermal cycler (BIORAD) amplifier. -13 T/C gene SAA1 polymorphism was detected by the amplification method with subsequent restriction enzyme digest analysis with Acil endonuclease 
Table I. Characteristics of groups of patients with rheumatoid arthritis

\begin{tabular}{|c|c|c|c|c|}
\hline Index & Grade & $\begin{array}{c}1^{\text {st }} \text { group } \\
\text { (AA-positive) }\end{array}$ & $\begin{array}{l}2^{\text {nd }} \text { group } \\
\text { (AA-negative) }\end{array}$ & $\begin{array}{l}\text { Statistical significance } \\
\text { of the difference }\end{array}$ \\
\hline \multirow[t]{2}{*}{ rheumatoid factor $n(\%)$} & positive & $36(80)$ & $43(73)$ & \multirow{2}{*}{$\begin{array}{l}\text { non-significant } \\
\quad(p=0.54)\end{array}$} \\
\hline & negative & $9(20)$ & $16(27)$ & \\
\hline \multirow[t]{3}{*}{ disease activity (SDAI) $n(\%)$} & 1 & 0 & 0 & \multirow{3}{*}{$\begin{array}{l}\text { non-significant } \\
\quad(p=0.8)\end{array}$} \\
\hline & 2 & $13(29)$ & $27(46)$ & \\
\hline & 3 & $32(71)$ & $32(54)$ & \\
\hline \multirow{4}{*}{$\begin{array}{l}\text { radiographic stage of the } \\
\text { disease } 4(\%)\end{array}$} & । & $1(2)$ & $1(2)$ & \multirow{4}{*}{$\begin{array}{l}\text { non-significant } \\
\quad(p=0.19)\end{array}$} \\
\hline & $\|$ & $3(7)$ & $12(20)$ & \\
\hline & III & $21(47)$ & $25(42)$ & \\
\hline & IV & $20(44)$ & $21(36)$ & \\
\hline
\end{tabular}

(Fermentas, Vilnius) and electrophoretic separation in 8\% polyacrylamide gel. Restriction was conducted strictly according to MBI Fermentas instructions. 2995 C/T and 3010 C/T gene SAA1 polymorphisms were detected by the amplification method with subsequent restriction enzyme digest analysis with Banl (2995) or Bcll (3010) endonuclease respectively. Both polymorphisms were detected separately. Detection of electrophoretic separation was conducted in $2 \%$ agarose gel under ultraviolet (UV) light with a Vilber Lourmat transilluminator (France). Results were documented with a Nikon 2100 digital camera.

\section{Detection of Chlamydia trachomatis infection}

The infection was detected either for Chlamydia trachomatis specific DNA fragments or culture of the bacteria (McCoy medium). Immunoglobulin A, M or G levels were either normal or negative. Previous work has revealed that this is quite typical for chronic chlamydial infection in RA patients [12]. In some cases for the aim of the research previous medical data confirming Chlamydia trachomatis infection was used.

All patients have no clinical or laboratory signs of any other infections with joint involvement, such as yersiniosis, Lyme-borreliosis, dysentery, etc.

\section{Statistical methods}

The obtained data was entered in a database (Microsoft Office Excel 2002, Microsoft Office). Statistical analysis was conducted with the STATISTICA 6.0 package (StatSoft. Inc., USA). Distribution of studied parameters was assessed by Shapiro-Wilk test. The results were expressed as median, upper and lower quartiles (25; 75\%). Non-parametric Mann-Whitney $U$ test was used for comparison of two inde- pendent groups. Statistical analyses of genotype and allele frequency comparisons of the various single nucleotide polymorphisms between the groups were performed using the $\chi^{2}$ test. Correlation between the two groups was assessed by the Gamma method for non-parametric data. We used the odds ratio (OR) to assess the risk of secondary amyloidosis. $P$ values less than 0.05 were considered statistically significant.

\section{Results}

\section{SAA1 gene polymorphism}

The genotype of -13T/C gene SAA1 polymorphism was established by heavy fragments -212 and 190 nucleotide

Table II. -13T/C gene SAA1 polymorphism in rheumatoid arthritis patients

\begin{tabular}{|lccc|}
\hline & $\begin{array}{c}\text { AA-positive } \\
\text { group }\end{array}$ & $\begin{array}{c}\text { AA-negative } \\
\text { group }\end{array}$ & $\begin{array}{c}\text { Statistical } \\
\text { significance } \\
\text { of the difference }\end{array}$ \\
\hline$n$ & 45 & 59 & \\
\hline $\begin{array}{l}\text {-13T/C gene SAA1 } \\
\text { polymorphism }\end{array}$ & $n(\%)$ \\
\hline$\pi$ & $0(0.0)$ & $0(0.0)$ & 0.5 \\
\hline TC & $10(22.2)$ & $12(20.3)$ & 0.5 \\
\hline CC & $35(77.8)$ & $47(79.7)$ \\
\hline Allele & & & \\
\hline$-13 T$ & $10(11.1)$ & $12(10.2)$ & 0.5 \\
\hline$-13 C$ & $80(88.9)$ & $106(89.8)$ & 0.5 \\
\hline
\end{tabular}


Table III. 2995C/T and 3010C/T gene SAA1 polymorphism in rheumatoid arthritis patients

\begin{tabular}{|c|c|c|c|c|c|c|}
\hline Genotype & & & $\begin{array}{l}\text { AA-positive } \\
\text { group }\end{array}$ & $\begin{array}{l}\text { AA-negative } \\
\text { group }\end{array}$ & $\begin{array}{c}\text { Statistical } \\
\text { significance } \\
\text { of the difference } \chi^{2}\end{array}$ & $\begin{array}{c}\text { Statistical } \\
\text { significance } \\
\text { of the difference } p\end{array}$ \\
\hline $2995 \mathrm{C} / \mathrm{T}$ & $3010 \mathrm{C} / \mathrm{T}$ & $\alpha, \beta, \gamma$ & $45 n(\%)$ & $59 n(5)$ & & \\
\hline TT & CC & $\alpha / \alpha$ & $43(95.6)$ & 19 (32.2) & 31.2 & $<0.001$ \\
\hline TC & CT & $\alpha / \beta$ & $2(4.4)$ & $16(27.1)$ & 10.3 & $<0.001$ \\
\hline TC & CC & $\alpha / \gamma$ & 0 & $10(16.9)$ & 6.6 & 0.005 \\
\hline CC & $\mathrm{TT}$ & $\beta / \beta$ & 0 & $9(15.3)$ & 5.71 & 0.005 \\
\hline CC & TC & $\beta / \gamma$ & 0 & $5(8.5)$ & 2.37 & 0.07 \\
\hline \multirow[t]{4}{*}{ CC } & CC & $\gamma / \gamma$ & 0 & 0 & & \\
\hline & $\alpha$ & & 88 (97.8\%) & $64(54.2)$ & 47.01 & $<0.001$ \\
\hline & $\beta$ & & $2(2.2 \%)$ & 39 (33.1) & 25.79 & \\
\hline & $\gamma$ & & 0 & 15 (12.7) & 10.5 & \\
\hline
\end{tabular}

pairs. Results of -13T/C gene SAA1 polymorphism detection are presented in Table II. No significant differences between the two patient groups were revealed. Therefore, the -13T allele is not obligatory for AA amyloidosis development in Belarusian patients with RA.

Results of 2995 C/T and 3010 C/T gene SAA1 polymorphism determination are summarized in Table III.

Comparison of groups on genotype and three allele frequencies showed statistically significant differences. The most notable differences were observed in SAA1 $\alpha / \alpha$ genotype $-\chi^{2}=31.1(p<0.001)$. As a result it was revealed that up 43 of 45 AA-positive RA patients had SAA1 $\alpha / \alpha$ geno-

Table IV. Odds ratio for different variants of SAA1 genotype

\begin{tabular}{|ccc|}
\hline \multicolumn{2}{|c|}{ OR } & Cl \\
\hline Genotype & & \\
\hline$\alpha / \alpha$ & 45.26 & $9.9-206.8$ \\
\hline$\alpha / \beta$ & 37.13 & $8.71-57.9$ \\
\hline$\alpha / \gamma$ & 0 & - \\
\hline$\beta / \beta$ & 0 & - \\
\hline$\beta / \gamma$ & 0 & - \\
\hline Allele & & \\
\hline$\alpha$ & 37.13 & $8.71-57.9$ \\
\hline$\beta$ & 0.05 & $0.01-0.2$ \\
\hline$\gamma$ & 0 & - \\
\hline
\end{tabular}

type while only $32.2 \%$ AA-negative RA patients presented this genotype. A similar tendency was observed for allele $\alpha$ frequency: $\chi^{2}=47.01(p<0.001)$.

It is of interest that the SAA1 $\gamma / \gamma$ genotype was not revealed in both groups. This genotype variant is considered to be a risk factor of secondary amyloidosis in Japanese RA patients [13]. Furthermore, in AA-positive patients the $\gamma$ allele was not found at all. Thus, presence of the $\gamma$ allele can be considered to be "protective" as it was detected in the AA-negative group only.

The OR for SAA $\alpha / \alpha$ genotype was 45.26 with $95 \% \mathrm{Cl}$ 9.9-206.8 (Table IV). Relative risk of secondary amyloidosis significantly increases in patients with $\alpha / \alpha$ genotype. Therefore, this genotype variant is a genetic risk factor of secondary amyloidosis in Belarusian patients with RA.

Statistical analysis showed a strong correlation between the $\alpha$ allele and secondary amyloidosis $(R=1 ; p<0.001)$. At the same time presence of the $\gamma$ allele reduces probability of this RA complication $(\mathrm{R}=-1 ; p<0.001)$. The $\beta$ allele acts similarly $(\mathrm{R}=-0.01 ; p<0.001)$. Hence, the $\alpha$ allele is a significant risk factor for secondary amyloidosis in RA, while $\beta$ and $\gamma$ alleles have a protective influence.

The -13T allele of the SAA1 gene (-13T/C locus) was present in $10.2 \%$ of AA-positive and in $11.1 \%$ of AA-negative RA patients $(p=0.5)$. There were no homozygous - $13 \mathrm{~T} / \mathrm{T}$ patients in either group. Thus, the -13T allele is not a risk factor of amyloidosis in Belarusian patients with RA.

\section{Chlamydia trachomatis infection}

Chlamydia trachomatis infection was found in 38 of 45 patients in the AA-positive group (84\%). In the AA-nega- 
tive group the infection was found in $10 / 59$ patients (17\%) $(p=0.004)$.

Evaluation of medical documentation of the patients additionally revealed significant differences. More than a half of the patients in the AA-positive group (28/45; 62\%) had atypical onset of RA (asymmetric joint involvement, synovitis of the knee joint). Some of them had fever and received antibacterial medication. In the AA-negative group only 7 patients (12\%) had atypical joint involvement at onset of the disease.

According to our observations, RA patients with increased risk of secondary amyloidosis are characterized by a number of clinical features. They more often have knee joint involvement at the disease onset $(P=0.03)$ and less often hand joint involvement $(P=0.02)$. At the same time, joint lesions are often asymmetric $(P=0.002)$. Treatment with disease-modifying antirheumatic drugs is commonly less effective in those patients.

Cumulative influence of SAA1 $\alpha / \alpha$ genotype and Chlamydia trachomatis infection.

We have analyzed possible risk factors for development of secondary amyloidosis in RA patients including those indicated in the literature. The obtained results are presented in Table V. Odds ratio for combination of SAA1 $\alpha / \alpha$ genotype and Chlamydia trachomatis infection increases to 55.0 (95\% Cl: 10.2-154.3).

\section{Discussion}

Development of secondary amyloidosis is a complex phenomenon related to a number of factors [3]. It is well known that a prolonged, severe inflammation is one of the major factors contributing to the development of amyloidosis. On the other hand, other factors are involved in this process.

In the present study, we have found that SAA $1 \alpha / \alpha$ isotype is the most amyloidogenic in Belarusian Caucasian patients. Relative risk of secondary amyloidosis in RA patients with SAA1 $\alpha / \alpha$ genotype is significantly higher (OR = 45.26; 95\% Cl: 9.9-206.8). This finding is consistent with the reports of Baba et al. [9] and Moriguchi et al. [10], who described the association of $\alpha / \alpha$ genotype with juvenile arthritis and rheumatoid arthritis complicated by amyloidosis.

In contrast, the $\gamma / \gamma$ genotype was reported to be a "risk genotype" for development of amyloidosis in Asian patients suffering from RA [14].

The obtained results suggest that Chlamydia trachomatis infection is an additional risk factor for development of amyloidosis in RA patients. The mechanism of this phenomenon remains unclear. Chlamydial infection induces inflammation that itself is an amyloidosis-inducing factor. It is also possible that Chlamydia trachomatis exerts specific immune stimulation resulting in amyloid deposition. Further studies in this field are needed.
Table V. Risk factors of secondary amyloidosis in RA patients

\begin{tabular}{|c|c|c|}
\hline Risk factor & OR & $\mathrm{Cl}$ \\
\hline$S A A 1 \alpha / \gamma, \beta / \beta, \beta / \gamma$ & 0 & - \\
\hline$S A A 1 \gamma$ & 0 & - \\
\hline$S A A 1 \beta$ & 0.05 & $0.01-0.2$ \\
\hline Hydroxychloroquine & 0.26 & $0.1-0.63$ \\
\hline Methotrexate & 0.45 & $0.18-1.14$ \\
\hline Sulfasalazine & 0.59 & $0.27-1.29$ \\
\hline Sex & 0.83 & $0.29-2.36$ \\
\hline RF positivity & 1.49 & $0.59-3.77$ \\
\hline Glucocorticoids & 3.38 & $1.42-8.06$ \\
\hline $\begin{array}{l}\text { Chlamydia trachomatis } \\
\text { infection }\end{array}$ & 26.6 & $9.36-76.37$ \\
\hline$S A A 1 \alpha$ & 37.13 & $8.7-157.9$ \\
\hline$S A A 1 \alpha / \alpha$ & 45.26 & 9.9-206.8 \\
\hline $\begin{array}{l}\text { Cumulative effect of } \\
\text { Chlamydia trachomatis } \\
\text { infection + SAA1 ?/? } \\
\text { genotype }\end{array}$ & 55 & $10.2-154.3$ \\
\hline
\end{tabular}

From a practical clinical point of view, detection and management of chlamydial infection (including re-infection) seems to be an important component of the therapeutic strategy in RA patients.

Determination of SAA1 polymorphism is still not a routine procedure in management of RA patients but it is recommended in cases with signs of early amyloidosis in order to introduce more aggressive therapy (including biologics with special anti-inflammatory activity, e.g. tocilizumab).

The authors declare no conflict of interest.

\section{References}

1. Hazenberg BP, van Rijswijk MH. Where has secondary amyloid gone? Ann Rheum Dis 2000; 59: 577-579.

2. Sanmartí R, Gómez-Casanovas E, Solé M, et al. Prevalence of silent amyloidosis in rheumatoid arthritis and its clinical significance. J Rheumatol 2004; 31: 1013-1014.

3. Kucharz EJ. Amyloidoses. In: Internal medicine. Januszewicz W, Kokot F (eds.). Wydawnictwo Lekarskie PZWL, Warsaw 2006, vol. 3: 1396-1401 (in Polish).

4. Bergesio F, Ciciani AM, Santostefano M, et al. Renal involvement in systemic amyloidosis - an Italian retrospective study on epidemiological and clinical data at diagnosis. Nephrol Dial Transplant 2007; 22: 1608-1618. 
5. Hazenberg BP, van Gameren II, Bijzet J, et al. Diagnostic and therapeutic approach of systemic amyloidosis. Neth J Med 2004; 62: 121-128.

6. Okuda Y, Takasugi K. Diagnostic and prognostic study of secondary amyloidosis complicating rheumatoid arthritis. Amyloid and Amyloidosis. Parthenon Publishing Group, New York 1998: 426-428.

7. Cunnane G, Grehan S, Geoghegan S, et al. Serum amyloid A in the assessment of early inflammatory arthritis. J Rheumatol 2000; 27: 58-63.

8. Kuroda T, Tanabe N, Harada T, et al. Long-term mortality outcome in patients with reactive amyloidosis associated with rheumatoid arthritis. Clin Rheumatol 2005; 25: 1-8.

9. Baba S, Masago SA, Takahashi T, et al. A novel allelic variant of serum amyloid A, SAA1 $\gamma$ : genomic evidence, evaluation, frequency, and implication as a risk factor or reactive systemic AA-amyloidosis. Hum Mol Genet 1995; 4: 1083-1087.

10. Moriguchi M, Terai C, Kaneko H, et al. A novel single-nucleotide polymorphism at the 5'-flanking region of SAA1 associated with risk of type AA amyloidosis secondary to rheumatoid arthritis. Arthritis Rheum 2001; 44: 1266-1272.

11. Mavragani CP, Yiannakouris N, Zintzaras E, et al. Analysis of SAA1 gene polymorphisms in the Greek population: rheumatoid arthritis and FMF patients relative to normal controls. Amyloid 2007; 14: 271-275.

12. Soroka NF. Rheumatoid arthritis associated with chlamydial infection. Zdravoohranenie 2009; 1: 4-9 (in Russian).

13. Arnett FC, Edworthy SM, Bloch DA, et al. The American Rheumatism Association 1987 revised criteria for the classification of rheumatoid arthritis. Arthritis Rheum 1988; 31: 315-324.

14. Ajiro J, Narita I, Sato F, et al. SAA1 gene polymorphisms and the risk of AA amyloidosis in Japanese patients with rheumatoid arthritis. Mod Rheumatol 2006; 16: 294-299. 